Vol. 4 No. 1 (2021) : 13 - 27

Available online at http://jurnal.unissula.ac.id/index.php/fikri/issue/archive

\title{
GOOGLE CLASSROOM SEBAGAI ALTERNATIF E-LEARNING PEMBELAJARAN SKI PADA MASA PANDEMI COVID 19 DI MA HIDAYATULLAH
}

\author{
Soimatul Khomisah ${ }^{1}$, Sigit Tri Utomo ${ }^{1}$, Ana Sofiyatul Azizah ${ }^{1}$ \\ ${ }^{1}$ INISNU Temanggung, Jawa Tengah \\ Email : Edu.soimatul@madrasah.id, sigittriutomosukses@gmail.com
}

\begin{abstract}
This study discusses the application of the google classroom as an alternative to e-learning for learning SKI (Islamic Cultural History) class XII during the Covid-19 pandemic at MA Hidayatullah. This study aims to determine how the implementation of google classroom, the inhibiting factors and supporting factors as well as the solutions taken to overcome the inhibiting factors. This research is a descriptive qualitative research. The subjects of this study were students of class XII, teachers who used the google classroom application and principals of madrasah. Methods of data collection in this study using the method of observation, interviews and documentation. The data validity technique in this study used triangulation of sources and methods. The collected research data is analyzed using interactive analysis with data reduction steps, data display and verification (conclusion). Based on the results of the research, the authors can conclude that the application of the google classroom application in learning SKI class xii ma Hidayatullah is going well supported by several factors, namely the ease of finding reference sources, is not bound by time and place and is easy to understand while the inhibiting factors are found is a weak signal and data quota / packet is limited. These two inhibiting factors can be overcome by providing concessions on deadlines for sending assignments and submitting online learning facilities to the relevant government.
\end{abstract}

Key Word: Google Classroom, E-learning, Islamic Cultural History

Abstrak:

Penelitian ini membahas tentang penerapan google classroom sebagai alternatif e-learning pembelajaran SKI (Sejarah Kebudayaan Islam) kelas XII pada masa pandemi covid-19 di MA Hidayatullah. Penelitian ini bertujuan untuk mengetahui bagaimana implementasi google classroom, faktor penghambat dan faktor pendukung serta solusi yang diambil untuk mengatasi faktor penghambat. Penelitian ini merupakan penelitian kualitatif deskriptif. Subjek penelitian ini adalah siswa kelas XII, guru pengguna aplikasi google classroom dan kepala madrasah. Metode pengumpulan data pada penelitian ini menggunakan metode observasi, wawancara dan dokumentasi. Teknik keabsahan data pada penelitian ini dengan menggunakan triangulasi sumber dan metode. Data penelitian yang terkumpul dianalisis menggunakan analisis interaktif dengan langkah-langkah reduksi data (data reduction), penyajian data (data display) dan verifikasi (conclusion). Berdasarkan hasil penelitian, penulis dapat mengambil kesimpulan bahwa, penerapan aplikasi google classroom pada pembelajaran SKI kelas xii ma hidayatullah berjalan dengan baik dengan didukung oleh beberapa faktor yakni kemudahan dalam mencari sumber referensi, tidak terikat oleh waktu dan tempat serta mudah difahami sedangkan faktor penghambat yang ditemukan adalah sinyal lemah dan kuota/paket data terbatas. Kedua faktor penghambat ini dapat diatasi dengan pemberian kelonggaran pada tenggat waktu pengiriman tugas dan pengajuan fasilitas sarana pembelajaran daring terhadap pemerintah terkait.

Kata Kunci : Google Classroom, E-learning, Sejarah Kebudayaan Islam 


\section{Pendahuluan}

Pandemi COVID-19 telah memunculkan beragam dampak pada berbagai bidang dan sektor, termasuk di bidang pendidikan. Hal ini telah menimbulkan kepanikan masyarakat apalagi setelah pemerintah pusat secara beruntun menyikapinya dengan bermacam tindakan seperti menetapkan status siaga, darurat bencana, bencana non-alam, perpanjangan status darurat bencana hingga pembatasan sosial berskala besar (PSBB). Jumlah korban yang semakin hari terus bertambah dan sebaran virusnya semakin sulit dikendalikan di seluruh penjuru Indonesia memjadikan pemerintah memberlakukan upaya pencegahan COVID 19 berupa social \& physical distancing.

Melalui Surat Edaran Mendikbud RI No 3 Tahun 2020 tentang Pencegahan COVID-19 pada satuan Pendidikan, Surat Edaran Menteri Pendidikan dan Kebudayaan Nomor 4 Tahun 2020 tentang pelaksanaan kebijakan pendidikan dalam masa darurat Pencegahan Penyebaran Corona Virus Disease (Covid-19) dan Surat Edaran Dirjen Pendidikan Islam Kementerian Agama RI Nomor 285.1 Tahun 2020 tentang Upaya Pencegahan Virus Covid-19, semua lembaga pendidikan di Indonesia mengambil langkah tegas atas himbauan pemerintah untuk melakukan aktivitas belajar dari rumah demi pencegahan dan percepatan penurunan wabah COVID-19. Kebijakan dan fenomena pandemi yang dampaknya luar biasa dan terjadi begitu cepat telah memaksa dunia pendidikan mengubah pola kerja pelayanan dari konvensional menjadi pelayanan berbasis online. Begitu juga Madrasah Aliyah Hidayatullah Pringsurat Temanggung (Kemendikbud, 2020)

Madrasah Aliyah Hidayatullah adalah sebuah Madrasah Aliyah dibawah naungan Yayasan Pondok Pesantren Hidayatullah Tuksongo, yang berlokasi di dusun Tuksongo desa Nglorog kecamatan Pringsurat kabupaten Temanggung provinsi Jawa Tengah. Selain jenjang aliyah, Yayasan ini juga menyelenggarakan pendidikan tingkat Tsanawiyah, Diniyah dan Pendidikan Anak Usia Dini. Madrasah ini baru berdiri enam tahun terakhir dengan dua Jurusan yaitu IPA dan IPS. Sebagai upaya pelaksanaan proses belajar mengajar pada masa pandemic COVID-19 Madrasah Aliyah Hidayatullah memanfaatkan berbagai layanan e-learning salah satunya adalah Google Classroom. Tanpa kecuali pada pembelajaran Sejarah Kebudayaan Islam, salah satu mata pelajaran wajib yang telah ditentukan oleh dirjen pendidikan islam. Jadi tidak heran kalau angka download aplikasi ini langsung melesat di masa pandemi COVID-19 dikalangan peserta didik sendiri. Sungguh melegakan dan sedikit menghibur melihat ada begitu banyak platform gratis tersedia sehingga guru dan murid bisa tetap melakukan kegiatan belajar mengajar dan tetap terhubung (Soni, 2018).

Desain Google classroom diperuntukan bagi pengajar, peserta didik, wali dan administrator. Guru dapat menggunakan fasilitas membuat dan mengelola kelas, tugas, nilai serta memberikan masukan secara langsung (real-time). Peserta didik sendiri dapat memantau materi dan tugas kelas, berbagi materi dan berinteraksi dalam aliran kelas atau melalui email, mengirim tugas dan mendapat masukan dan nilai secara langsung. Adapun wali dapat memanfaatkan ringkasan email yang memuat tugas peserta didik. Ringkasan ini 
meliputi informasi tentang tugas yang tidak dikerjakan, tugas selanjutnya dan aktivitas kelas. Namun wali tidak bisa login ke kelas secara langsung. Wali hanya menerima ringkasan email melalui akun lain. Untuk administrator dapat membuat, melihat atau menghapus kelas di domainnya, menambahkan atau menghapus peserta didik dan pengajar dari kelas serta melihat tugas di semua kelas di domainnya (Harjanto, dkk, 2006).

Google classroom merupakan suatu serambi pembelajaran campuran yang diperuntukkan terhadap setiap ruang lingkup pendidikan yang dimaksudkan untuk menemukan jalan keluar atas kesulitan dalam membuat, membagikan dan menggolonggolongkan setiap penugasan tanpa kertas. Dari definisi tersebut tersurat jelas tujuannya, yaitu memudahkan pendidik dalam pembelajaran dan memberikan tugas-tugas tanpa kertas. Tujuan ini seirama dengan pembejaran digital yang meminimalisisir penggunaan kertas dan pemanfaatan teknologi. Prinsipnya, Google classroom hanya sebuah media atau alat yang dapat digunakan oleh pendidik dan peserta didik untuk menciptakan kelas online atau kelas virtual, di mana pendidik dan peserta didik dapat melakukan pembelajaran secara langsung. Sebagai bawaan dari perusahaan raksasa Google, Google classroom memiliki akses di lebih dari 45 negara

\section{Metode}

Pada penelitian ini penulis menggunakan jenis penelitian kualitatif. Penelitian kualitatif adalah proses untuk memahami masalah sosial berdasarkan metodologi yang berbeda. Dalam hal ini, peneliti akan menyusun gambaran yang kompleks, menganalisa kata demi kata dan menyusun hasil penelitian secara natural/sesuai fakta dilapangan. Bogdan dan Taylor mendefinisikan metode kualitatif sebagai prosedur penelitian yang menghasilkan data deskriptif berupa kata-kata tertulis lisan dari orang-orang dan perilaku yang dapat diamati. Kirk dan Miller mendefinisikan bahwa penelitian kualitatif adalah tradisi tertentu dalam ilmu pengetahuan sosial yang secara fundamental bergantung dari pengamatan pada manusia baik dalam kawasannya maupun dalam peristilahnya (Moleong, 2006).

Sedangkan Sugiyono mengemukakan bahwa metode kualitatif ialah metode penelitian yang berlandaskan pada filsafat postpositivisme, digunakan untuk meneliti pada obyek yang alamiah, dimana peneliti adalah sebagai instrumen kunci, pengambilan sampel sumber data dilakukan secara purposive dan snowball, teknik penelitian trianggulasi (gabungan), analisis data bersifat induktif/kualitatif, dan hasil penelitian kualitatif lebih menekankan makna daripada generalisasi (Sugiyono, 2008).

Selain definisi-definisi diatas, ada definisi penelitian kualitatif lainnya seperti yang dikemukakan oleh David Williams bahwa penelitian kualitatif adalah pengumpulan data pada suatu latar alamiah, dengan menggunakan metode alamiah, dan dilakukan oleh peneliti yang tertarik secara alamiah. Jelas definisi ini menggambarkan bahwa penelitian kualitatif mengutamakan latar alamiah, agar hasilnya dapat digunakan untuk menafsirkan fenomena, dan metode yang biasanya digunakan adalah wawancara, pengamatan, dan 
pemanfaatan dokumen (Moleong, 2006).

Penelitian ini menggunakan metode kualitatif karena peneliti menganggap permasalahan yang diteliti cukup kompleks dan dinamis sehingga data yang diperoleh dari para narasumber tersebut dijaring dengan metode yang lebih alamiah yakni interview langsung dengan para narasumber sehingga didapatkan jawaban yang alamiah. Selain itu, peneliti bermaksud untuk memahami situasi sosial secara mendalam, menemukan pola, hipotesis, dan teori yang sesuai dengan data yang diperoleh di lapangan.

Penelitian kualitatif tidak pernah terlepas dari istilah analisis fenomenologi. Peneliti dalam pandangan fenomenologis berusaha memahami peristiwa dan kaitannya terhadap orang-orang yang berada dalam situasi tertentu (Moleong, 2006). Seperti yang dilakukan pada penelitian ini, peneliti melakukan kajian di bidang sosiologi dan antropologi selain kajian di bidang manajemen sumber daya manusia dan psikologi industri untuk membantu peneliti dalam mengintrepretasikan fenomena atau situasi sosial yang diteliti.

\section{Hasil dan Pembahasan}

\section{Google Classroom}

a. Pengertian Google Classroom

Menurut Abdul Barir Hakim, Google Classroom adalah layanan berbasis Internet yang disediakan oleh Google sebagai sebuah sistem $e^{-}$ learning. Service ini didesain untuk membantu pengajar membuat dan membagikan tugas kepada pelajar secara paperless (Rusman, 2015). Pengguna service ini harus mempunyai akun di Google. Selain itu Google Classroom hanya bisa digunakan oleh sekolah yang mempunyai Google Apps for Education.

Dengan demikian Google Classroom merupakan suatu aplikasi yang disediakan oleh Google for Education untuk menciptakan ruang kelas dalam dunia maya. Aplikasi ini dapat membantu memudahkan guru dan siswa dalam melaksanakan proses belajar dengan lebih mendalam. Pembelajaran dengan menggunakan rancangan kelas yang mengaplikasikan Google Classroom sesungguhnya ramah lingkungan. Hal ini dikarenakan siswa tidak lagi menggunakan kertas dalam mengumpulkan tugasnya.

Pemanfaatan Google Classroom dapat melalui multiplatform yakni melalui komputer dan telepon genggam. Guru dan siswa dapat mengunjungi situs https://classroom.google.com atau mengunduh aplikasi melalui playstore di android atau app store di IOS dengan kata kunci Google Classroom.

\section{b. Fungsi Google Classroom}

Google Classroom merupakan sebuah produk bagian dari Google for Education yang sangat istimewa, karena produk yang satu isi memiliki banyak fasilitas didalamnya seperti memberi pengumuman atau tugas, mengumpulkan tugas dan melihat siapa saja yang sudah mengumpulkan tugas. 
Pada situs Google Classroom juga tertulis bahwa Google Classroom terhubung dengan semua layanan Google For Education yang lainnya, sehingga pendidik dapat memanfaatkan Google Mail, Google Drive, Google Calendar, Google Docs, Google Sheets, Google Slides, dan Google Sites dalam proses pembelajarannya. Sehingga saat pendidik menggunakan Google Classroom pendidik juga dapat memanfaatkan Google Calendar untuk mengingatkan peserta didik tentang jadwal atau tugas yang ada, sedangkan penggunaan Google Drive sebagai tempat untuk menyimpan keperluan pembelajaran seperti Power Point, file yang perlu digunakan dalam pembelajaran maupun yang lainnya. Dengan demikian, Google Classroom dapat membantu memudahkan guru dan siswa dalam melaksanakan kegiatan belajar mengajar dengan lebih mendalam. Hal ini disebabkan karena baik siswa maupun guru dapat mengumpulkan tugas, mendistribusikan tugas, dan berdiskusi tentang pelajaran dimanapun tanpa terikat batas waktu atau jam pelajaran. Hal tersebut membuat proses pembelajaran lebih menarik dan lebih efisien dalam hal pengelolaan waktu, dan tidak ada alasan lagi siswa lupa tentang tugas yang sudah diberikan oleh guru (diemas, 2017).

\section{c. Langkah Langkah Membuat Google Classroom}

Dalam pembuatan akun google clasroom, ada beberapa langkah yang perlu ditempuh, langkah langkah tersebut akan penulis uraikan sebagai berikut:

Hal yang pertama, kita buka terlebih dahulu email kita (WAJIB dengan account Gmail.com), setelah itu di halaman sebelahnya kita buka kembali URL atau Link https://classroom.google.com langsung enter, akan tampil gambar berikut:

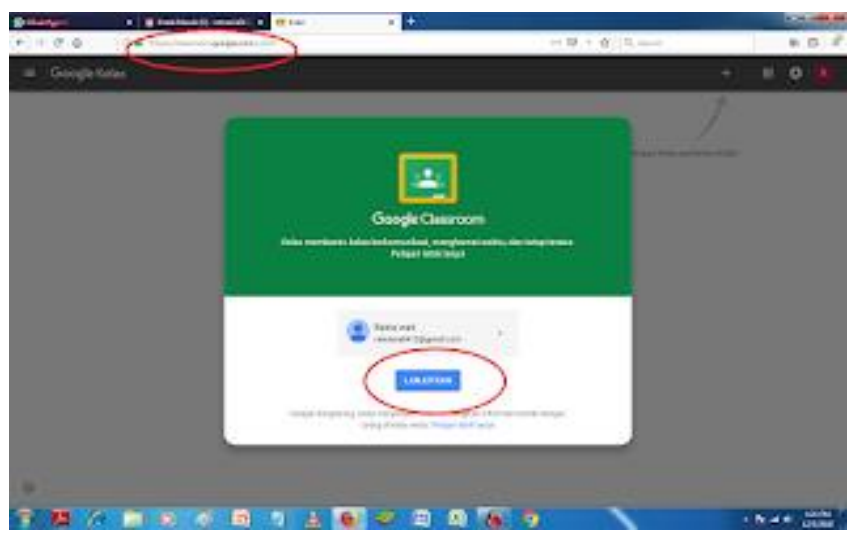

Gambar 2.1 tampilan awal google classroom

setelah tampil gambar di atas, klik " Lanjutkan"

Setelah proses pertama selesai akan tampil tampilan gambar di bawah dan tahapan selanjutnya klik tanda Tambah $(+)$ pada sudut kanan layar. 


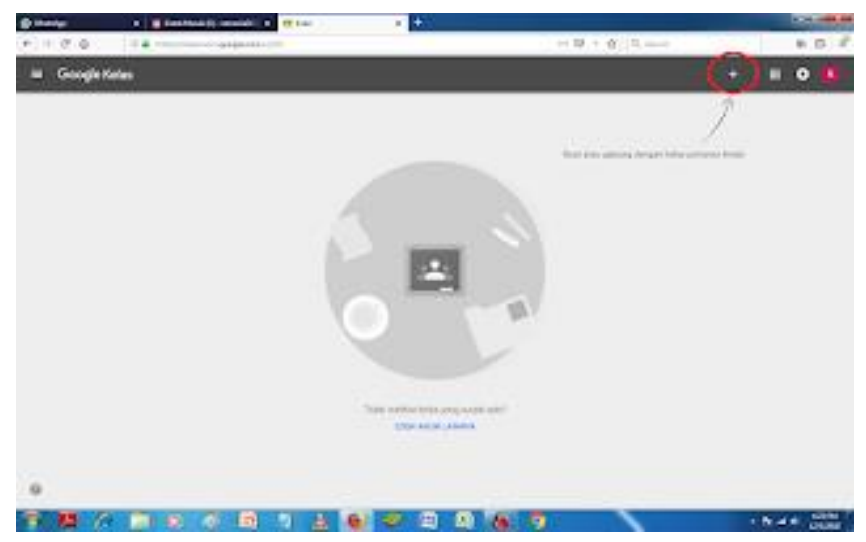

Gambar 2.2 menu tambah akun

Setelah proses tahap ke 2 akan ada 2 pilihan, yaitu " Gabung dengan kelas" dan " Buat Kelas", maka pilih " Buat Kelas".

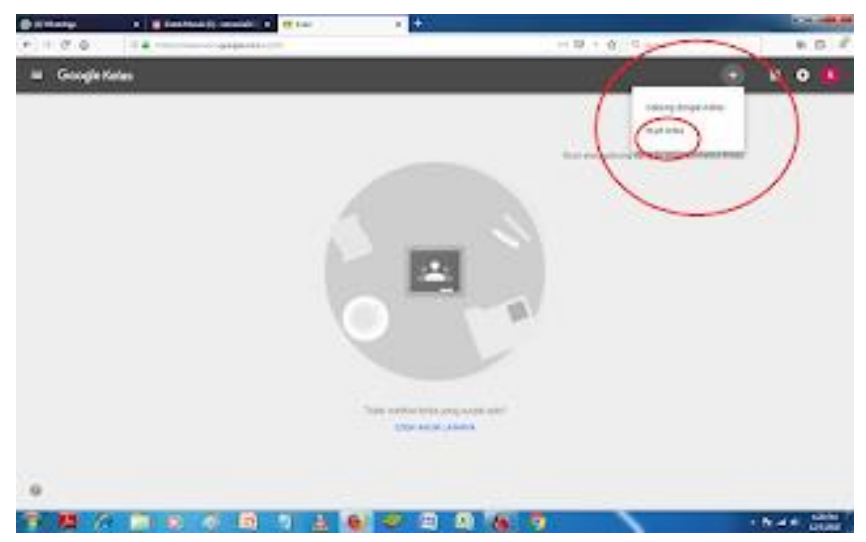

Gambar 2.3 menu gabung dengan kelas dan buat kelas

Selanjutnya akan tampil dialog yang mewajibkan lalu centang dialog tersebut dan langsung klik "Lanjutkan"

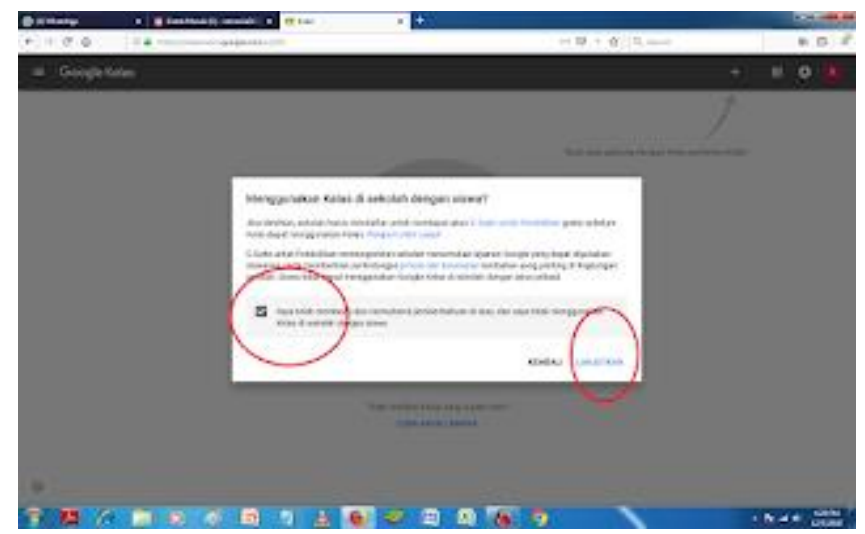

Gambar 2.4 kolom dialog lanjutan

Selanjutnya akan di sajikan tampilan dialog pengisian data kelas, di sini diisi yang wajib yaitu data kelas. Isi dengan Mata pelajaran yang kita ingin jadikan Pembelajaran. 


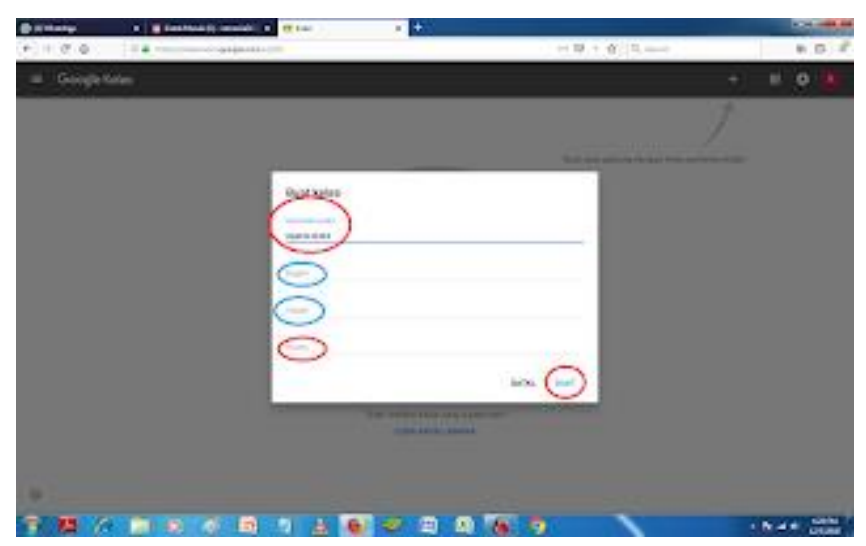

Gambar 2.5 kolom identitas kelas

Setelah proses ini selesai, akan tampil dialog dan harus diklik tanda silang atau ok.

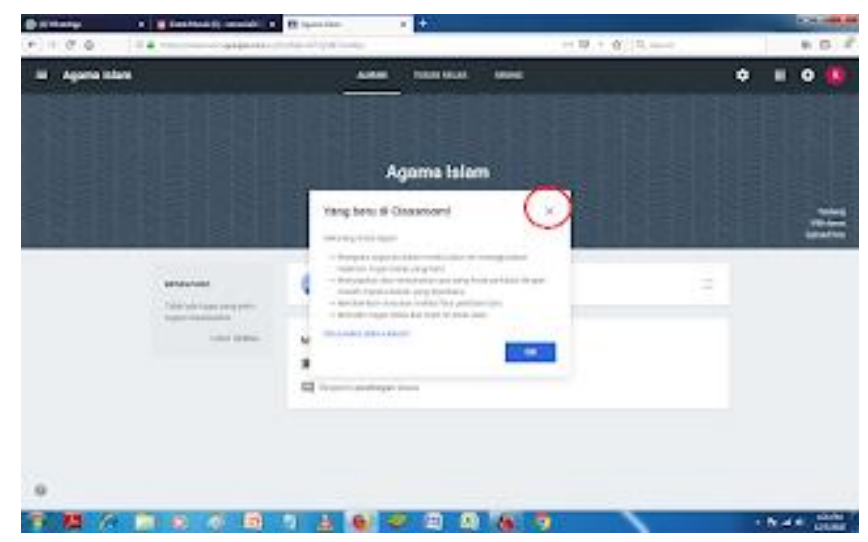

Gambar 2.6 dialog pilihan

Setelah tahap ini selesai, maka akan disajikan ruang kerja atau tampilan kerja untuk menginput data materi atau media kita sebagai sumber belajar.

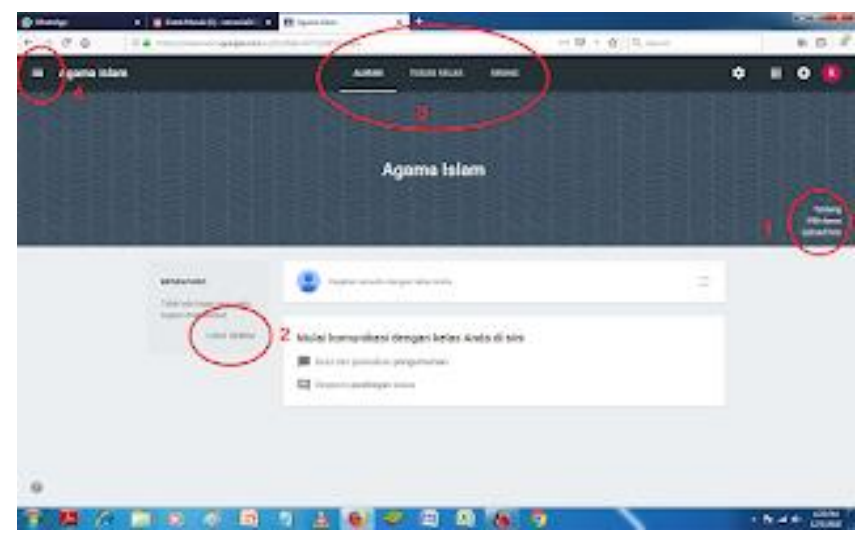

Tahap ini dibagi menjadi 4 bagian, yaitu: Mengenai Tema tampilan ruang kerja, Mengenai Materi apa saja yang telah kita isi di dalam 1 account email yang telah kita daftarkan di google classroom, mengenai Seluruh materi/media yang telah diupload dapat berupa dokumen, video atau link youtube.com yang menjadi 
media dalam memberikan materi, mengenai profil, dan menambah materi baru (Bloggerpelajar.or.id, 2020).

Setelah semua tahapan selesai maka selanjutnya dapat mengundang siswa untuk bergabung ke kelas dengan cara menampilkan kode kelas.

\section{d. Kelebihan Dan Kekurangan Google Classroom}

1) Kelebihan google classroom

Menurut Janzen M dan Mary yang dikutip dalam Shampa Iftakhar menyatakan kelebihan dari Google Classroom antara lain yaitu:

a) Mudah digunakan: Sangat mudah digunakan. Desain Google Kelas sengaja menyederhanakan antarmuka instruksional dan opsi yang digunakan untuk tugas pengiriman dan pelacakan; komunikasi dengan keseluruhan kursus atau individu juga disederhanakan melalui pemberitahuan pengumuman dan email.

b) Menghemat waktu: Ruang kelas Google dirancang untuk menghemat waktu. Ini mengintegrasikan dan mengotomatisasi penggunaan aplikasi Google lainnya, termasuk dokumen, slide, dan spreadsheet, proses pemberian distribusi dokumen, penilaian, penilaian formatif, dan umpan balik disederhanakan dan disederhanakan.

c) Berbasis cloud : Google Classroom menghadirkan teknologi yang lebih profesional dan otentik untuk digunakan dalam lingkungan belajar karena aplikasi Google mewakili sebagian besar alat komunikasi perusahaan berbasis claud yang digunakan di seluruh angkatan kerja profesional.

d) Fleksibel: Aplikasi ini mudah diakses dan dapat digunakan oleh instruktur dan peserta didik di lingkungan belajar tatap muka dan lingkungan online sepenuhnya. Hal ini memungkinkan para pendidik untuk mengeksplorasi dan memengaruhi metode pembelajaran yang dibalik lebih mudah serta mengotomatisasi dan mengatur distribusi dan pengumpulan tugas dan komunikasi dalam beberapa milieus instruksional.

e) Gratis: Google Kelas sendiri sudah dapat digunakan oleh siapapun untuk membuka kelas di Google kelas asalkan memiliki akun gmail dan bersifat gratis. Selain itu dapat mengakses semua aplikasi lainnya, seperti Drive, Documents, Spreadsheets, Slides, dll. Cukup dengan mendaftar ke akun Google.

f) Ramah seluler: Google Classroom dirancang agar responsif. Mudah digunakan pada perangkat mobile manapun. Akses mobile ke materi pembelajaran yang menarik dan mudah untuk berinteraksi sangat penting dalam lingkungan belajar terhubung web saat ini (Shampa, 2016). 
2) Kekurangan google classroom

Google Classroom yang berbasis berbasis web mengharuskan siswa dan guru untuk terkoneksi dengan internet.

a) Pembelajaran berupa individual sehingga mengurangi pembelajaran sosial peserta didik.

b) Apabila peserta didik tidak kritis dan terjadi kesalahan materi akan berdampak pada pengetahuannya.

c) Membutuhkan spesifikasi hardware, software dan jaringan internet yang tinggi (Indah, 2018)

\section{E-learning}

\section{a. Pengertian E-learning}

Menurut Jaya Kumar C. Koran (2002) yang dikutip oleh Rusman, E-learning adalah pembelajaran yang menggunakan rangkaian elektronik (LAN, WAN, atau internet) untuk menyampaikan isi pembelajaran, interaksi, atau bimbingan. Menurut Smaldino yang dikutip Dewi Salma Prawiradilaga, Elearning adalah proses belajar yang memanfaatkan sumber belajar bersifat elektronik, dan berbantuan komputer, namun tidak selalu harus berhubungan dengan internet (Dewi, 2013).

Menurut Som Naidu (2006) yang dikutip oleh Dewi Salma Prawiradilaga, E-learning sebagai penggunaan secara sengaja jaringan teknologi informasi dan komunikasi dalam proses belajar dan mengajar. Istilah lain yang mengacu pada hal yang sama, yaitu online learning, virtual learning, distributed learning, atau web-based learning. Secara fundamental, menurut Prawiradilaga e-learning adalah proses pendidikan yang memanfaatkan teknologi informasi dan komunikasi untuk memediasi aktivitas pembelajaran baik secara sinkronous yaitu pembelajaran yang dilaksanakan guru dan peserta didik dalam waktu yang bersamaan maupun asinkronous yaitu pembelajaran yang dilakukan guru dan peserta didik tidak dalam waktu yang bersamaan.

Menurut Khan (2005) yang dikutip dalam I Kadek Suartama bahwa e-learning menunjuk pada pengiriman materi pembelajaran kepada siapapun, di manapun, dan kapanpun dengan menggunakan berbagai teknologi dalam lingkungan pembelajaran yang terbuka, fleksibel dan terdistribusi. Lebih jauh, istilah pembelajaran terbuka dan fleksibel merujuk pada kebebasan peserta didik dalam hal mengefisienkan waktu, tempat, kecepatan, isi materi, gaya belajar, jenis evaluasi, belajar kolaborasi atau mandiri (Kadek, 2014).

Dengan demikian dapat disimpulkan bahwa e-learning adalah suatu proses pembelajaran dengan menggunakan seperangkat alatalat elektronik sebagai sumber dan media penunjang agar terlaksananya proses kegiatan belajar mengajar yang tidak terbatas oleh ruang dan waktu. 
Menurut Rashty (1999) yang dikutitp oleh Dewi Salma Prawiradilaga terdapat beberapa metode e-learning adalah sebagai berikut:

\section{b. Model E-learning}

1) Model Adjunct. Model ini dapat dikatakan sebagai proses pembelajaran yang tradisional. Artinya pembelajaran tradisional yang ditunjang dengan sistem penyampaian secara online sebagai pengayaan .keberadaan sistem penyampaian secara online merupakan suatu tambahan.

2) Model Mixed/Blended. Model Blended menempatkan sistem penyampaian secara online sebagai bagian yang tidak terpisahkan dari proses pembelajaran secara keseluruhan. Artinya baik proses tatap muka maupun pembelajaran secara online merupakan satu kesatuan utuh.

3) Model Online Penuh (Fully Online). Dalam model ini semua interaksi pembelajaran dan penyampaian bahan belajar terjadi secara online.

\section{Pembelajaran}

Pembelajaran pada hakikatnya merupakan interaksi antara guru dengan siswa, baik interaksi secara langsung seperti kegiatan tatap muka maupun secara tidak langsung, yaitu dengan menggunakan berbagai media pembelajaran.

Menurut Hamzah B. Uno dalam (Rusman, 2013) Pembelajaran dapat diartikan sebagai suatu proses interaksi antara peserta belajar dengan pengajar atau instruktur dan sumber belajar pada suatu lingkungan belajar untuk mencapai tujuan belajar tertentu. Dengan demikian, pembelajaran merupakan subsistem dari suatu penyelenggaraan pendidikan atau pelatihan (training).

Menurut M. Irham dan Novan Ardy, Istilah pembelajaran hampir sama dengan istilah teaching dan instruction. Pembelajaran dikaitkan dengan proses dan usaha yang dilakukan oleh guru atau pendidik untuk melakukan proses penyampaian materi kepada siswa melalui pengorganisasian materi, siswa, dan lingkungan yang umumnya terjadi di dalam kelas (M. Irham, 2013).

pembahasan mengenai implementasi google classroom sebagai alternatif e-learning pembelajaran SKI, akan dibahas secara tegas dan di pertajam melalui kajian teori seperti pembahasan yang ada pada bab sebelumnya. Akan tetapi peneliti perlu mempertegas kembali bahwa data penelitian ini diperoleh melalui observasi partisipatif yang dilakukan oleh peneliti, wawancara dengan informan dan dokumentasi.

Sesuai yang telah dipaparkan peneliti membagi tiga poin pembahasan yaitu:

1. Implementasi google classroom sebagai alternatif e-learning pembelajaran SKI kelas XII pada masa pandemi COVID-19 di MA Hidayatullah

Dari sajian data di atas, Keunggulan pemanfaatan google sebagai media pembelajaran adalah mudah dipakai dan dipahami karena tampilannya simple dan menarik. Akses yang cepat bias digunakan 
dimana saja, kapan saja, dengan menginstal app google classroom lewat playstore.

Dalam hal ini penerapan ide atau konsep yang dikembangkan dalam pelaksanaan pembelajaran berbasis e-learning memberikan dampak baik bagi peserta didik dan kemajuan madrasah, salah satu contoh yaitu bertambahnya pengetahuan, keterampilan, maupun sikap yang harus disiasati selama proses belajar di dalam jaringan tanpa tatap muka. Hal ini sesuai dengan yang diungkapkan Muhammad Joko Susilo dalam buku yang berjudul implementasi manajemen peningkatan mutu pendidikan Islam, peningkatan lembaga pendidikan Islam secara holistik (M. Fathurrohman, dkk, 2012).

Selain itu, dalam e-learning dapat diterapkan pula metode diskusi. Hal ini sesuai dengan metode pembelajaran islami yang terdapat pada Al-Qur'an surat An-Nahl ayat 125 yakni metode hikmah, metode nasehat baik/mauidhoh hasanah dan metode diskusi. Diskusi memberikan peluang sebesar-besarnya kepada para siswa untuk mengeksplor pengetahuan yang dimilikinya kemudian dipadukan dengan pendapat siswa lain. Dalam penelitian implementasi google classroom sebagai alternatif e-learning pembelajaran SKI kelas XII pada masa pandemi COVID-19 di MA Hidayatullah Kecamatan Pringsurat Kabupaten Temanggung ini siswa melaksanakan pembelajaran dengan berdiskusi dengan teman secara virtual.

Peneliti dapat mengolongkan tahapan tahapan implementasi google classroom meliputi tahap perencanaan, tahap pelaksanaan dan evaluasi/penilaian. Hal ini sesuai dengan teori yang di kemukakan oleh Oemar Malik bahwa secara garis besar implementasi meliputi tahap perencanaan, pelaksanaan dan evaluasi (oemar, 2011).

2. Faktor pendukung dan faktor penghambat implementasi google classroom sebagai alternatif e-learning pembelajaran SKI kelas XII pada masa pandemi COVID-19 di MA Hidayatullah

a. Faktor pendukung

1) Kemudahan dalam mencari sumber referensi

Pembelajaran menggunakan aplikasi google classroom memudahkan siswa dalam menemukan lebih banyak sumber referensi dari internet. Hal ini sesuai dengan teori yang dikemukakan oleh Janzen $M$ dan Mary yang dikutip dalam Shampa Iftakhar yang mengatakan bahwa google classroom sangat mudah digunakan dan fleksible. Desain Google Kelas sengaja menyederhanakan antar muka instruksional dan opsi yang digunakan untuk tugas pengiriman dan pelacakan. Komunikasi dengan keseluruhan kursus atau individu juga disederhanakan melalui pemberitahuan pengumuman dan email. Aplikasi ini dikatakan fleksibel karena mudah diakses dan dapat digunakan oleh instruktur dan peserta didik di lingkungan belajar tatap muka dan lingkungan online sepenuhnya. Hal ini memungkinkan 
para pendidik untuk mengeksplorasi dan memengaruhi metode pembelajaran yang dibalik lebih mudah serta mengotomatisasi dan mengatur distribusi dan pengumpulan tugas dan komunikasi dalam beberapa milieus instruksional (Shampa, 2016).

Dalam e-learning pembelajaran SKI kelas XII dapat dikatakan berjalan dengan cukup baik meskipun dilakukan secara online sepenuhnya. Hal ini membuktikan bahwa aplikasi google classroom mudah digunakan dan sangat fleksibel untuk dijadikan alternatif pembelajaran pada masa pandemi COVID-19 bahkan dapat digunakan pasca pandemi sebagai media untuk melaksanakan ujian kompetensi pengetahuan peserta didik sebagai upaya untuk menghemat penggunaan kertas.

2) Tidak terikat oleh waktu dan tempat

Faktor pendukung lain dalam implementasi google classroom sebagai alternatif e-learning pembelajran SKI kelas XII pada masa pandemi COVID-19 yaitu tidak terikat oleh waktu dan tempat hal ini sesuai dengan teori yang dikemukakan oleh Janzen $\mathrm{M}$ dan Mary yang dikutip dalam Shampa Iftakhar bahwa ruang kelas google dirancang untuk menghemat waktu. Ini mengintegrasikan dan mengotomatisasi penggunaan aplikasi Google lainnya, termasuk dokumen, slide, dan spread sheet, proses pemberian distribusi dokumen, penilaian, penilaian formatif, dan umpan balik disederhanakan (Shampa, 2016). Disamping itu Google Classroom dirancang agar responsif. Mudah digunakan pada perangkat mobile manapun. Akses mobile ke materi pembelajaran yang menarik dan mudah untuk berinteraksi sangat penting dalam lingkungan belajar terhubung web saat ini. Oleh karena itu setiap siswa kelas XII dapat mengikuti pembelajaran SKI melalui aplikasi google classroom dimanapun dan kapanpun.

Hal ini sesuai dengan teori yang dikemukakan oleh Dewi Salma Prawiradilaga yang mengatakan bahwa e-learning adalah proses pendidikan yang memanfaatkan teknologi informasi dan komunikasi untuk memediasi aktivitas pembelajaran baik secara sinkronous yaitu pembelajaran yang dilaksanakan guru dan peserta didik dalam waktu yang bersamaan maupun asinkronous yaitu pembelajaran yang dilakukan guru dan peserta didik tidak dalam waktu yang bersamaan (Dewi, 2013). Aktifitas pembelajaran SKI kelas XII selama masa pandemi COVID-19 di MA Hidayatullah melalui aplikasi google classroom yang dilakukan oleh peneliti dilakukan baik secara sinkronous dan asinkronous.

3) Mudah dipahami

Berdasar hasil temuan, peneliti dapat menarik kesimpulan sementara bahwa pembelajaran menggunakan aplikasi google classrooom mudah dipahami oleh siswa baik penggunaan aplikasinya maupun materi pemebelajaran yang disampaikan. 
Hal ini berdasar pada teori yang dikemukakan oleh Janzen M dan Mary bahwa google classroom sendiri sudah dapat digunakan oleh siapapun untuk membuka kelas di google classroom asalkan memiliki akun gmail dan bersifat gratis. Selain itu dapat mengakses semua aplikasi lainnya, seperti Drive, Documents, Spread sheets, Slides, dan lain sebagainya cukup dengan mendaftar ke akun Google. Oleh sebab itu, siswa kelas XII MA Hidayatullah dapat mengakses, mempelajari, menggunakan aplikasi google classroom sebagai sarana pembelajran pada masa pandemi COVID-19 dengan mudah dan faham.

b. Faktor penghambat

Berdasar hasil temuan, faktor penghambat dalam implementasi aplikasi google classroom sebagai alternatif e-learning pembelajaran SKI kelas XII pada masa pandemi COVID-19 di MA Hidayatullah Kecamatan Pringsurat Kabupaten Temanggung adalah sebagai berikut:

1) Sinyal lemah

2) Kuota/paket data terbatas

Kedua faktor penghambat ini merupakan konsekuensi kelemahan bagi aplikasi google classroom sebagai mana yang di kemukakan oleh Indah Lestari dalam jurnalnya. Terdapat 3 kelemahan google classroom yang dikemukakan oleh indah salah satunya adalah Membutuhkan spesifikasi hardware, software dan jaringan internet yang tinggi (Indah, 2018). Tingginya kecepatan jaringan internet di pengaruhi oleh sinyal dan kuota/paket data yang memadai.

3. Solusi yang diambil untuk mengatasi faktor penghambat implementasi google classroom sebagai alternatif e-learning pembelajaran SKI kelas XII pada masa pandemi COVID-19 di MA Hidayatullah

a. Sebagai upaya untuk mengatasi kendala sinyal, guru memberikan kelonggaran waktu pengiriman tugas

b. Sebagai upaya untuk mengatasi kendala keterbatasan kuota, sekolah mengupayakan pengajuan bantuan kuota sehingga didapat fasilitas untuk melengkapi sarana pembelajaran daring berupa kartu perdana $10 \mathrm{gb}$ dan uang tunai 15 juta rupiah.

\section{Kesimpulan}

Berdasarkan hasil penelitian kualitatif dengan teknik observasi, wawancara dan dokumentasi yang dilaksanakan di kelas XII MA Hidayatullah kecamatan Pringsurat Kabupaten Temanggung tentang implementasi google classroom sebagai alternatif e-learning pembelajaran SKI dapat diambil beberapa kesimpulan. Kesimpulan tersebut dipaparkan sebagai berikut:

1. Implementasi google classroom sebagai alternatif e-learning pembelajaran SKI kelas XII pada masa pandemi COVID-19 di MA Hidayatullah meliputi tahap perencanaan, pelaksanaan dan evaluasi oleh karena itu, 
implementasi google classroom sebagai alternatif e-learning pembelajaran SKI kelas XII pada masa pandemi COVID-19 di MA Hidayatullah sudah sesuai dengan prosedur yang ideal.

2. Faktor pendukung dan faktor penghambat implementasi google classroom sebagai alternatif $e$-learning pembelajaran SKI kelas XII pada masa pandemi COVID-19 di MA Hidayatullah adalah sebagai berikut:

a. Faktor pendukung

1) Kemudahan dalam mencari sumber referensi

2) Tidak terikat oleh waktu dan tempat

3) Mudah dipahami

b. Faktor penghambat

1) Sinyal lemah

2) Kuota/paket data terbatas

3. Solusi yang diambil untuk mengatasi faktor penghambat implementasi google classroom sebagai alternatif e-learning pembelajaran SKI kelas XII pada masa pandemi COVID-19 di MA Hidayatullah adalah sebagai berikut:

a. Sebagai upaya untuk mengatasi kendala sinyal, guru memberikan kelonggaran waktu pengiriman tugas

b. Sebagai upaya untuk mengatasi kendala keterbatasan kuota, sekolah mengupayakan pengajuan bantuan kuota sehingga didapat fasilitas untuk melengkapi sarana pembelajaran daring berupa kartu perdana $10 \mathrm{gb}$ dan uang tunai 15 juta rupiah.

\section{DAFTAR PUSTAKA}

Ad-Dimasyqi. 2003. Al-Imam Abul Isma'il Ibnu Kasir. Tafsir Ibnu Kasir; Juz 4 alHijr 2 S.D an-Nahl 128. Bandung: Sinar Baru Algensindo.

Al-Mahalli. 2011. Imam Jalaluddin dan As-Suyuti, Imam Jalaluddin. Terjemahan Tafsir Jalalain Berikut Asbabun Nuzul; jilid 1. Bandung: Sinar Baru Algesindo.

Deiniatur. 2019. "The Use of E-Learning through Google Classroom to Improve Students' Articulation Phonetic Ability." ELT-Echo 4 (2): 114-21.

Ditjen Pendis, 2020, Surat Edaran Ditjen Pendis Nomor 285 No 1 Tahun 2020 terkait Upaya Pencegahan Covid 19, dowload dari http://sulteng.kemenag.go.id/download/file/Surat_Edaran_Ditjen_Pendi s_Nomor_285_1_Tahun_2020.pdf."

El-Qurtuby, Usman. 2012.Al-Qur'an Cordoba. Bandung: PT Cordoba Internasional Indonesia.

Fathurrohman, Muhammad dan Sulistyorini. 2012. Implementasi Manajemen Peningkatan Mutu Pendidikan Islam, Peningkatan Lembaga Pendidikan Islam Secara Holistik. Yogjakarta:Teras.

Hakim, A.B., (2016). Efektifitas Penggunaan E-Learning Moodle,Google Classroom Dan Edmodo. I-STATEMENT: Information System and Technology Management, 2(1). 
Harjanto, Almio Susetyo, and Sri Sumarni. 2019. “Teacher's Experiences On The Use Of Google Classroom." 3rd English Language and Literature International Conference (ELLiC) 3: 172-78.

Harsono. 2008. Penelitian Kualitatif. Bandung: Rosda Karya.

I Kadek Suartama dan I Dewa Kade Tastra. 2014. E-learning Berbasis Moodle. Yogyakarta: Grahala Ilmu.

John W. Creswell. 2019. Research Design: Qualitative, Quantitative, Mixed Methods Approaches. Yogyakarta: Pustaka Pelajar.

Kemdikbud RI. 2020. "Edaran Tentang Pencegahan Wabah COVID-19 Di Lingkungan Satuan Pendidikan Seluruh Indonesia," 1-5.

M. Irham dan Novan Ardy W. 2016. Psikologi Pendidikan-Teori dan Aplikasi dalam Proses Pembelajaran.Yogyakarta: Ae-Ruzz Media.

Majid,Abdul. 2014. Implementasi Kurikulum 2013 Kajian Teoritis Dan Praktik. Bandung:Interesia.

Miles, Michael Huberman. 2007. Analisis Data Kualitatif. Jakarta: Universitas Indonesia Press.

Moleong, Lexy. 2006. Metodologi Penelitian Kualitatif (Edisi Revisi). Bandung : Remaja Rosda Karya

Rusman. 2013. Belajar dan Pembelajaran Berbasis Komputer Mengembangkan Profesionalisme Guru Abad 21.Bandung: Alfabeta.

Shihab, M. Quraish. 2002. Tafsir Al-Misbah; pesan. Kesan dan keserasian al-Qur'an. Jakarta: Lentera Hati.

, 2010. Al-Qur'an dan Maknanya. Jakarta: Lentera Hati.

Soni, Hafid, A., Hayami, R., Fatma, Y., Wenando, F. A., Amien, J. A.,Hasanuddin, H. (2018). Optimalisasi Penggunaan Google Classroom, E-Learning \& Blended Learning Sebagai Media Pembelajaran Bagi Guru Dan Siswa Di SMk Negeri 1 Bangkinang. Jurnal Pengabdian UntukMu NegeRI, 2(1), 17-20.

Sudjana, Nana. 2005. Cara Belajar Siswa Aktif-Dalam Proses Belajar Mengajar. Bandung:Sinar Baru.

Sugiyono. 2017. Metode Penelitian Kualitatif. Bandung: Alfabeta.

Sukmawati, Sukmawati, and Nensia Nensia. 2019. “The Role of Google Classroom in ELT." International Journal for Educational and Vocational Studies 1 (2): 142-45.

Tabi'in, Qoerul Ahmad. 2020. Google Classroom Sebagai Alternatif E-Learning Pembelajaran Akidah Ahlak Di Masa Pandemi Covid-19 Di Madrasah Aliyah Hidayatullah Pringsurat. Jurnal for education. 